\title{
Corrosion Behaviors of Al-Si-Cu-Based Filler Metals and 6061-T6 Brazements
}

\author{
T.L. Su, S.S. Wang, L.C. Tsao, S.Y. Chang, T.H. Chuang, and M.S. Yeh
}

(Submitted 17 September 2001)

\begin{abstract}
The corrosion behaviors of a series of Al-Si-Cu-based filler metals and the 6061-T6 butt joints brazed with these filler metals are evaluated by polarization tests and immersion tests in a $3.5 \% \mathrm{NaCl}$ aqueous solution. For comparison, a traditional Al-12Si filler metal is also employed. The results indicate that the Al-Si$\mathrm{Cu}$-based filler metals before brazing possess much higher corrosion current densities and pitting tendencies than the Al-12Si filler metal. However, brazing of the 6061-T6 alloy with an Al-12Si filler metal produces a wider butt joint, which, in this case, creates a more extensive corrosion region. Severe galvanic corrosion occurs at the 6061-T6 joints when brazed with Al-Si-Cu-based filler metals. However, in the case of the 6061-T6/Al-12Si brazements, selective corrosion of the Al-12Si eutectic phase can be observed. The bonding strengths of the 6061-T6 butt joints brazed with various filler metals are also measured before and after the immersion tests.
\end{abstract}

Keywords Al-Si-Cu-based filler metals, corrosion, 6061-T6 brazements

\section{Introduction}

Aluminum and its alloys, which possess high specific strength, good thermal conductivity, and superior corrosion resistance, have been widely used in the aerospace, automobile, and heat-exchangers industries. Brazing is one of the most important joining techniques for the manufacture of aluminum components. ${ }^{[1]}$ In order to achieve a satisfactory bonding effect, it is necessary for the brazing operation involving traditional Al-12Si filler metals ${ }^{[2,3]}$ to be conducted in the temperature range of 590 to $610{ }^{\circ} \mathrm{C}$. However, this is unacceptable to many aluminum engineering alloys because they may melt in the furnace or their mechanical properties may degenerate. To rectify these problems, a series of low-melting-point filler metals have been developed during the past few years. ${ }^{[4-6]}$ In a previous study by the authors, ${ }^{[6]}$ it was found that the Al-7Si$20 \mathrm{Cu}-2 \mathrm{Si}-1 \mathrm{Mg}$ filler metal possessed a melting temperature range of 501 to $522{ }^{\circ} \mathrm{C}$, and, when brazed with 6061-T6 aluminum at $550{ }^{\circ} \mathrm{C}$ for $60 \mathrm{~min}$ and subsequently undergoing a T6 treatment, the filler metal would achieve a bonding strength of $147 \pm 12 \mathrm{MPa}$. In contrast, the bonding strength was only $67 \pm$ $7 \mathrm{MPa}$ using the traditional $\mathrm{Al}-12 \mathrm{Si}$ filler metal at $600{ }^{\circ} \mathrm{C}$ for 60 min. $^{[6]}$

In practice, corrosion is an important and necessary consideration in the brazing of aluminum alloys, as it can be a major source of weakness for the brazement joints. Kuroda and colleagues ${ }^{[7,8]}$ reported that selective dissolution of the Al-Si eutectic phase was found in the Al-9Si filler metal after brazing,

T.L. Su, S.S. Wang, L.C. Tsao, S.Y. Chang, and T.H. Chuang, Institute of Materials Science and Engineering, National Taiwan University, Taipei 106, Taiwan; and M.S. Yeh, Department of Mechanical Engineering, Chung-Hua University, Hsin-Chu 300, Taiwan. Contact e-mail: tunghan@ccms.ntu.edu.tw.

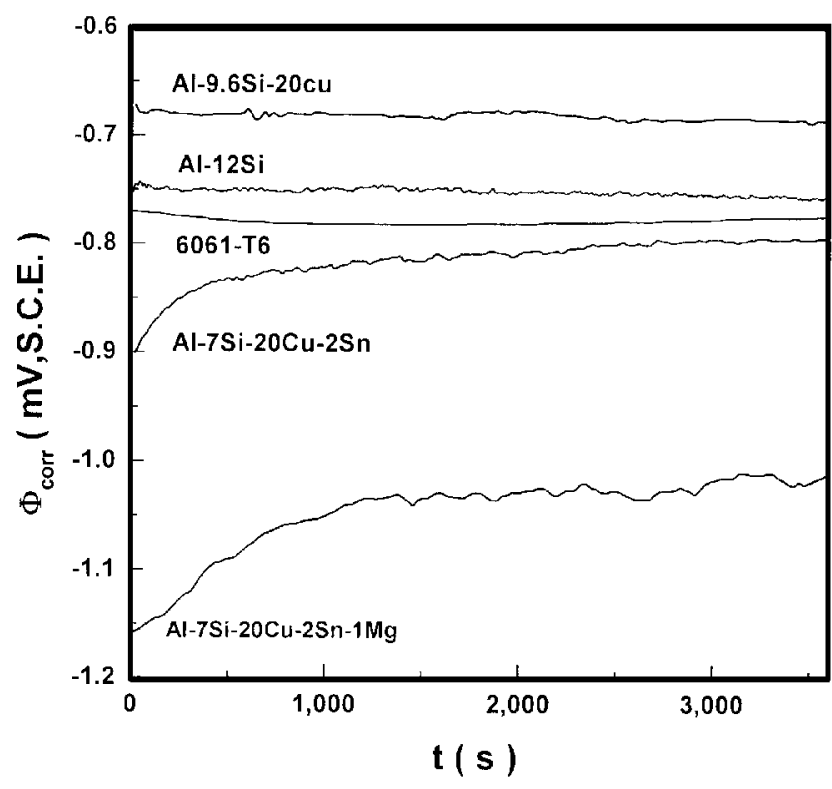

Fig. 1 Corrosion potential $\left(\Phi_{\text {corr }}\right)$ as a function of time $(t)$ for the 6061-T6 aluminum alloy, $\mathrm{Al}-\mathrm{Si}$, and $\mathrm{Al}-\mathrm{Si}-\mathrm{Cu}$-based filler metals in a $3.5 \% \mathrm{NaCl}$ aqueous solution

which effect was attributed to the pitting potential of the primary $\alpha$-Al phase being nobler than that of the Al-Si eutectic phase.

The effort of this study is concerned with the corrosion behaviors of the 6061-T6 aluminum alloys when brazed with $\mathrm{Al}-\mathrm{Si}-\mathrm{Cu}$-based filler metals such as Al-9.6Si-20Cu, Al-7Si$20 \mathrm{Cu}-2 \mathrm{Su}$, and $\mathrm{Al}-7 \mathrm{Si}-20 \mathrm{Cu}-2 \mathrm{Su}-1 \mathrm{Mg}$. For comparison, a traditional Al-12Si filler metal is also employed.

\section{Experimental}

$\mathrm{Al}-\mathrm{Si}$-Cu-based filler metals were prepared by melting an Al-12Si (wt.\%) alloy at $700{ }^{\circ} \mathrm{C}$ in alumina crucibles within an 


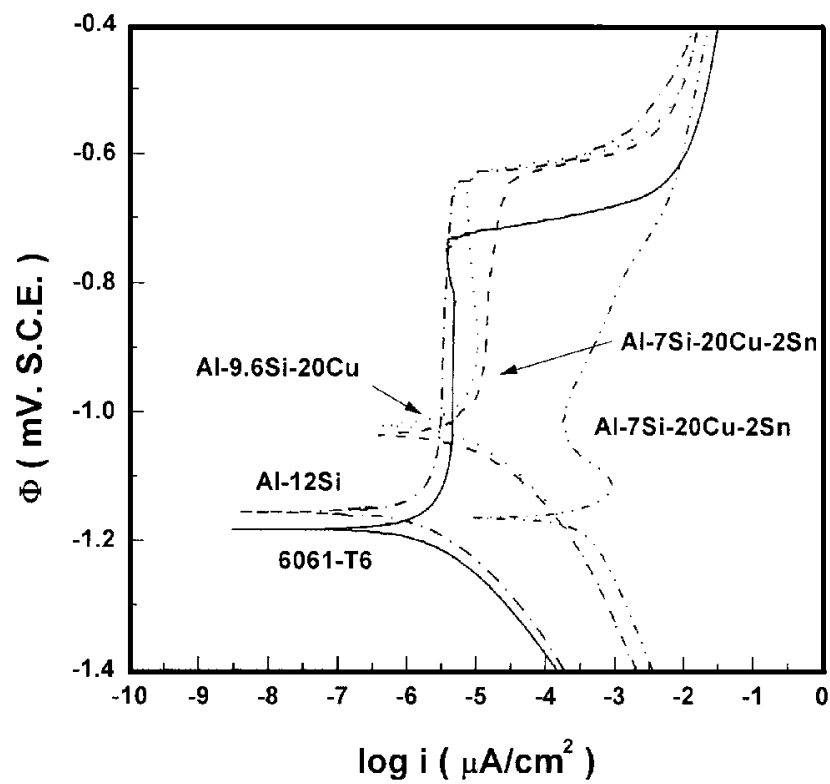

Fig. 2 Polarization curves of the 6061-T6 aluminum alloy, Al-Si, and $\mathrm{Al}-\mathrm{Si}-\mathrm{Cu}$-based filler metals in a $3.5 \% \mathrm{NaCl}$ aqueous solution
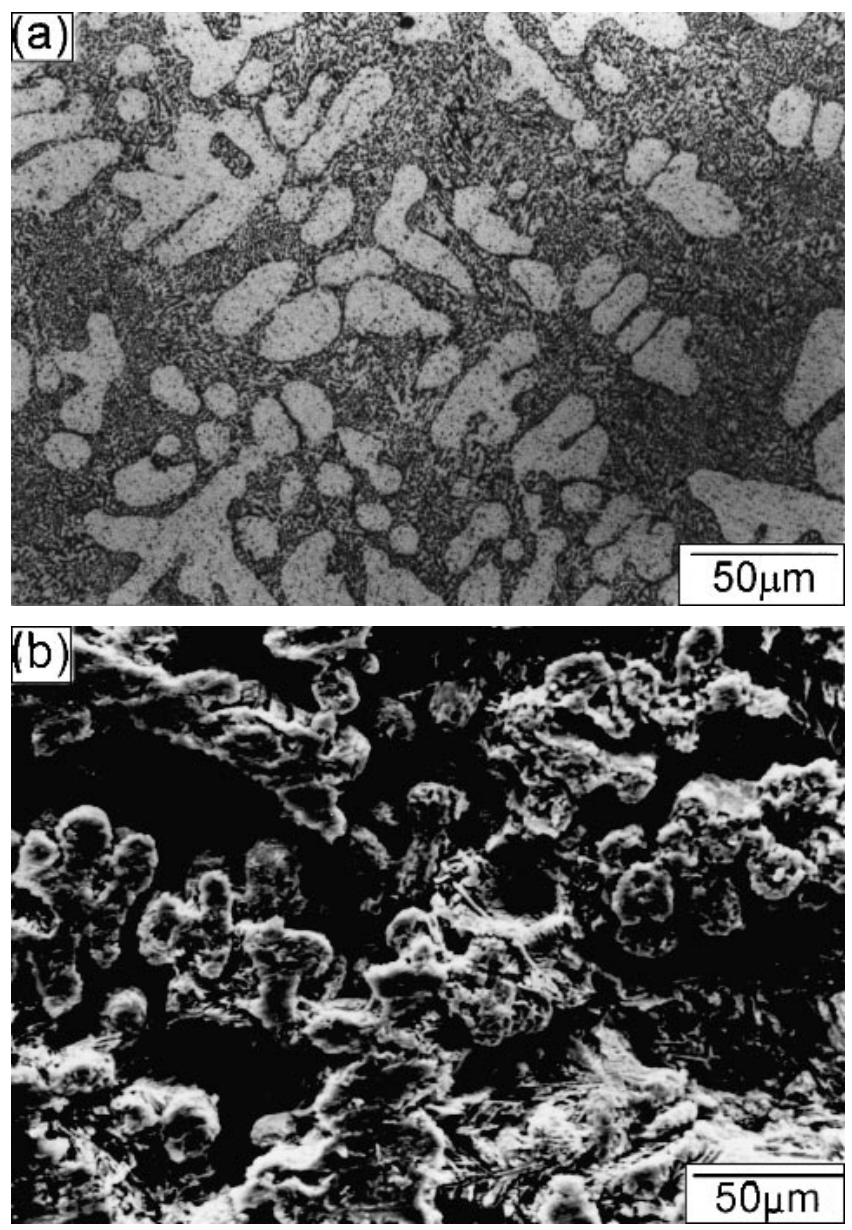

Fig. 3 Microstructure (a) and corroded surface (b) of the Al-12Si filler metal before brazing
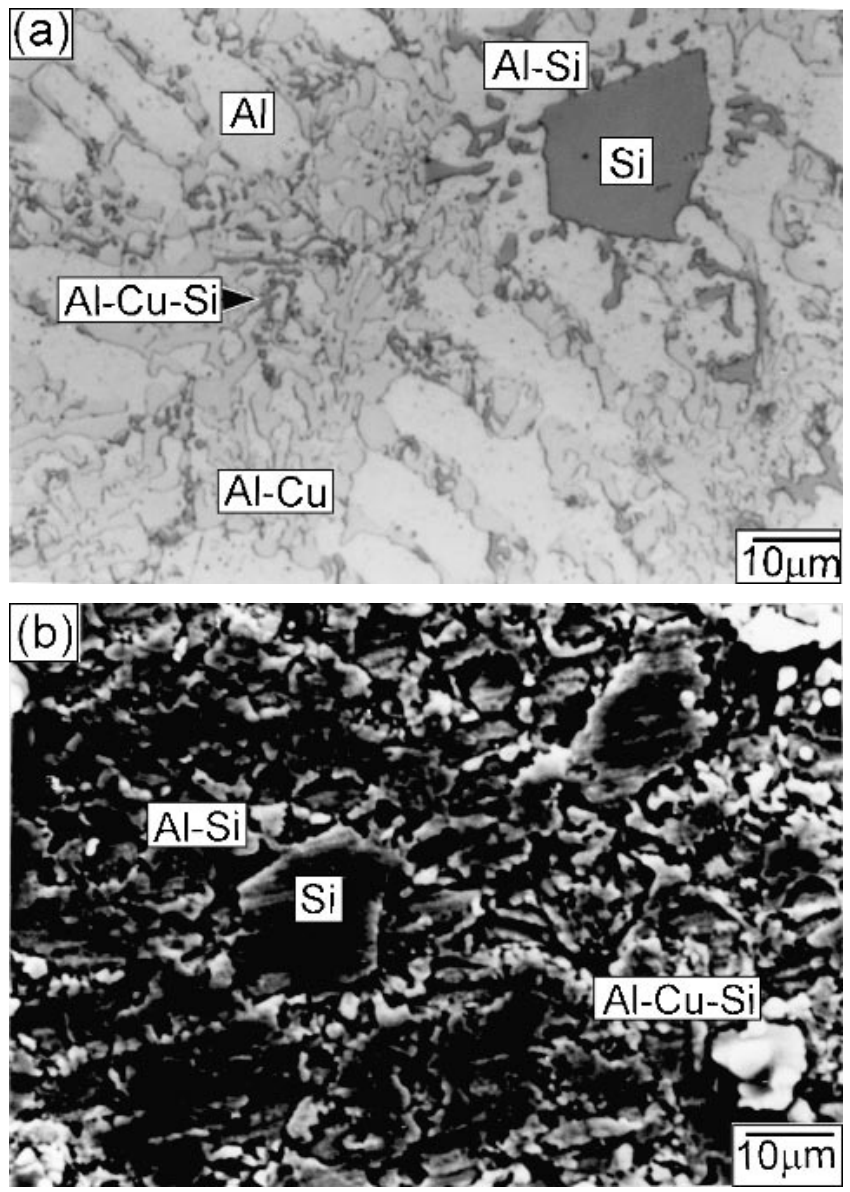

Fig. 4 Microstructure (a) and corroded surface (b) of the Al-9.6Si$20 \mathrm{Cu}$ filler metal before brazing

Table 1 Corrosion Data of 6061-T6 Aluminum Alloy, $\mathrm{Al}-12 \mathrm{Si}$, and $\mathrm{Al}-\mathrm{Si}-\mathrm{Cu}-\mathrm{Based}$ Filler Metals in a 3.5\% $\mathrm{NaCl}$ Aqueous Solution

\begin{tabular}{|c|c|c|c|c|c|}
\hline Materials & $\begin{array}{c}\boldsymbol{\Phi}_{\text {corr }} \\
\left(\mathbf{m} \mathbf{V}_{\text {SCE }}\right)\end{array}$ & $\begin{array}{c}\Phi_{\text {corr }}^{\mathbf{d}} \\
\left(\mathbf{m} \mathbf{V}_{\text {SCE }}\right)\end{array}$ & $\begin{array}{c}\boldsymbol{\Phi}_{\mathbf{b}} \\
\left(\mathbf{m} \mathbf{V}_{\text {SCE }}\right)\end{array}$ & $\begin{array}{c}\Delta \Phi \\
\left(\mathbf{m} \mathbf{V}_{\text {SCE }}\right)\end{array}$ & $\begin{array}{c}\mathbf{I}_{\text {corr }} \\
\left(\mu \mathrm{A} / \mathbf{c m}^{2}\right) \\
\end{array}$ \\
\hline 061-T6 & -774 & -1183 & -72 & 459 & 6.47 \\
\hline & -752 & -1 & -62 & -529 & 5.01 \\
\hline Al-9.6Si-20Cu & -680 & -1021 & -640 & 381 & 61.23 \\
\hline $\mathrm{Al}-7 \mathrm{Si}-20 \mathrm{Cu}-2 \mathrm{Sn}$ & -800 & -1026 & -643 & 383 & 62.87 \\
\hline $\mathrm{Al}-7 \mathrm{Si}-20 \mathrm{Cu}-1 \mathrm{Mg}$ & -1023 & -1154 & -1002 & 152 & 401.56 \\
\hline
\end{tabular}

$\Phi_{\text {corr }}$, corrosion potential (steady state); $\Phi_{\text {corr }}^{\mathrm{d}}$, dynamic corrosion potential; $\Phi_{\mathrm{b}}$, breakdown potential; $\Delta \Phi$, passive range $\left(=\Phi_{\mathrm{b}} \Phi_{\text {corr }}^{\mathrm{d}}\right) ; \mathrm{I}_{\text {corr }}$, corrosion current density.

air furnace. Afterward, the temperature was raised to $1000{ }^{\circ} \mathrm{C}$, followed by various amounts of copper (99.9 wt.\%, $2 \mathrm{~mm}$ diameter slug) being added to the molten Al-12Si alloy and then stirred for $30 \mathrm{~min}$ for homogenization. After the tin and magnesium elements were administered, the molten $\mathrm{Al}-\mathrm{Si}-\mathrm{Cu}$ alloy was finally cast in a stainless steel mold. Corrosion specimens were cut from the filler metal ingots, ground with 600grit $\mathrm{SiC}$ paper, and cleaned in acetone. All corrosion tests were 

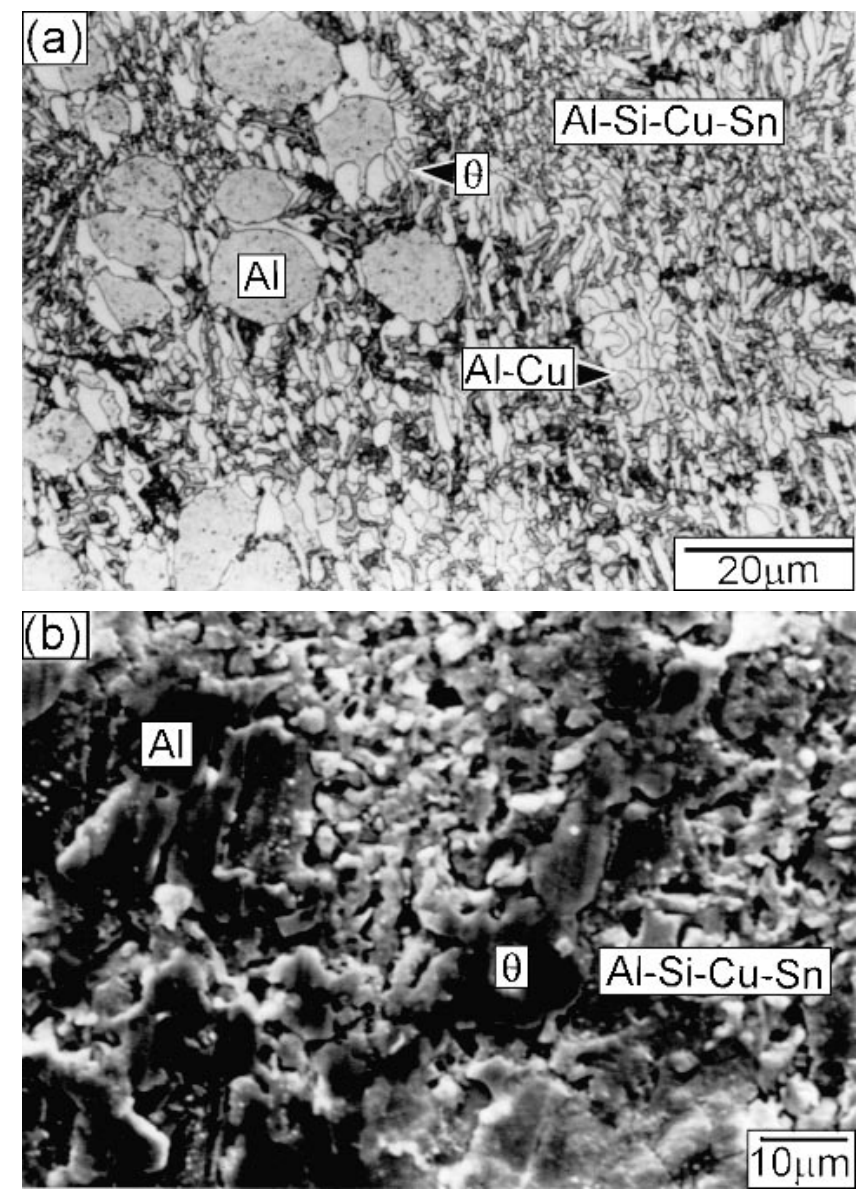

Fig. 5 Microstructure (a) and corroded surface (b) of the Al-7Si$20 \mathrm{Cu}-2 \mathrm{Sn}$ filler metal before brazing

performed at room temperature in a $3.5 \% \mathrm{NaCl}$ aqueous solution $(\mathrm{pH}=7.2)$ using a potentiostat (M273A, EG\&G Parc, $\mathrm{TN}$ ). During the dynamic potentiostatic polarization tests, the potential was first held at $-1500 \mathrm{mV}$ versus supersaturated calomel electrode (SCE) for $5 \mathrm{~min}$ to remove any oxide film formed prior to polarization testing, and then was polarized in the direction from active to noble at a scanning rate of $1 \mathrm{mV} / \mathrm{s}$.

In order to evaluate the corrosion attack on the aluminum alloy brazed with these Al-Si-Cu-based filler metals, the 6061T6 aluminum cylindrical specimens with diameters of $12 \mathrm{~mm}$ were employed. For bonding, an $0.2 \mathrm{~mm}$ thick filler metal was inserted between two 6061-T6 aluminum bars. The brazing process, using Al-Si-Cu-based filler metals, was carried out at $550{ }^{\circ} \mathrm{C}$ for $30 \mathrm{~min}$ in a vacuum furnace with pressure of $5 \times$ $10^{-5}$ torr. However, in the case of traditional Al-12Si filler metals, the brazing temperature should be raised to $600{ }^{\circ} \mathrm{C}$ due to their higher eutectic points (at about $577^{\circ} \mathrm{C}$ ). The specimens for tensile testing were prepared from the brazed samples; their geometry and dimensions had been shown in previous works of the authors. ${ }^{[6,9]}$ Respective numbers of specimens were immersed in a $3.5 \% \mathrm{NaCl}$ aqueous solution for 7 days and 30 days. The corroded surfaces of these specimens after immersion testing were observed through scanning electron microscopy. All the brazed specimens before and after immersion
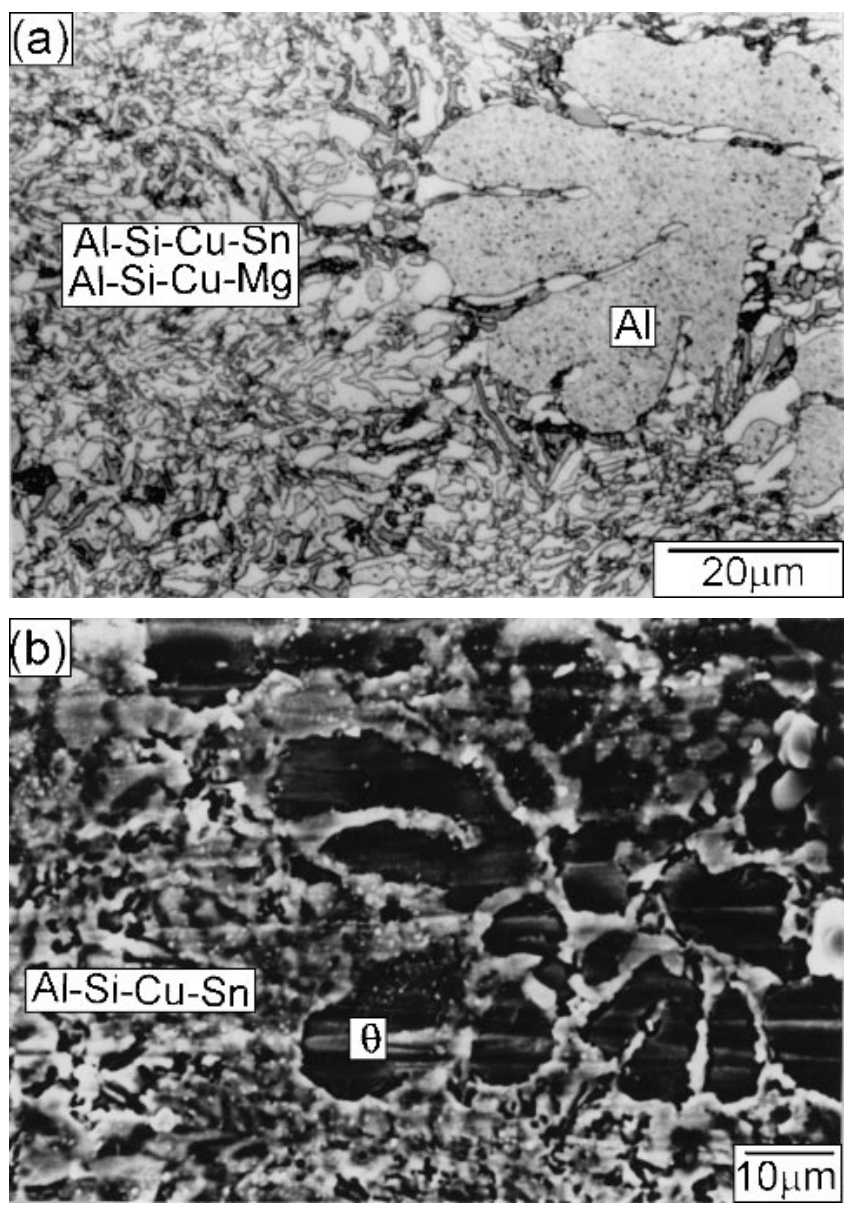

Fig. 6 Microstructure (a) and corroded surface (b) of the Al-7Si$20 \mathrm{Cu}-2 \mathrm{Sn}-1 \mathrm{Mg}$ filler metal before brazing

tests were subjected to tensile testing at a crosshead speed of $10^{-4} \mathrm{~ms}^{-1}$.

\section{Results and Discussion}

Figure 1 shows the corrosion potential of the as-cast Al-Si$\mathrm{Cu}$-based filler metals in a $3.5 \% \mathrm{NaCl}$ solution as a function of immersion time. For comparison, the corrosion potentials of 6061-T6 aluminum alloy and a traditional Al-12Si filler metal are also given in Fig. 1. It can be seen that the corrosion potentials decline in such order as $\mathrm{Al}-9.6 \mathrm{Si}-20 \mathrm{Cu}, \mathrm{Al}-12 \mathrm{Si}$, 6061-T6 alloys, Al-7Si-20Cu-2Sn, and Al-7Si-20Cu-2Sn-1Mg. As a result of addition of the active element $\mathrm{Mg}$ into the Al$\mathrm{Si}-\mathrm{Cu}$-based filler metal, the Al-7Si-20Cu-2Sn-1Mg alloy turns out to be one that possesses the most active corrosion potential. On the other hand, Al-9.6Si-20Cu reveals a more noble corrosion potential than Al-12Si and 6061-T6 aluminum alloy, which can be attributed to the high noble $\mathrm{Cu}$ content of that filler metal.

The potentiodynamic polarization curves of 6061-T6 aluminum alloy, $\mathrm{Al}-12 \mathrm{Si}$, and $\mathrm{Al}-\mathrm{Si}-\mathrm{Cu}$-based filler metals in a $3.5 \% \mathrm{NaCl}$ solution are shown in Fig. 2. The corrosion data obtained from the polarization curves are summarized in Table 

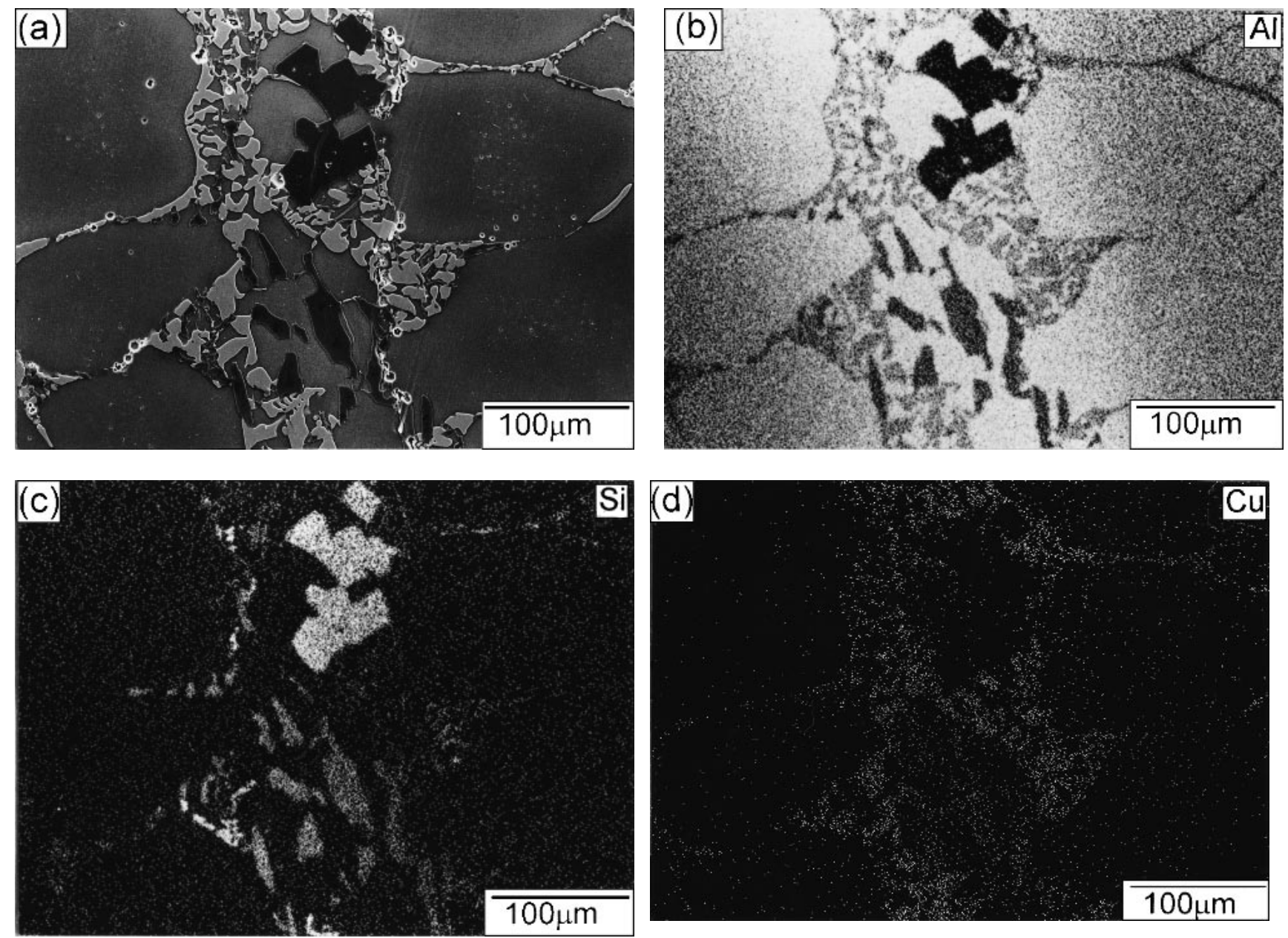

Fig. 7 Electron probe microanalyzer (EPMA) element mapping of the 6061-T6 butt joint brazed with the Al-9.6Si-20Cu filler metal at $550{ }^{\circ} \mathrm{C}$ for $30 \mathrm{~min}$

1. It is evident that the as-cast Al-Si-Cu-based filler metals possess higher corrosion current densities and stronger pitting tendencies than those of 6061-T6 aluminum alloy and Al-12Si filler metal.

The corroded surfaces of Al-12Si, Al-9.6Si-20Cu, Al-7Si$20 \mathrm{Cu}-2 \mathrm{Sn}$, and $\mathrm{Al}-7 \mathrm{Si}-20 \mathrm{Cu}-2 \mathrm{Sn}-1 \mathrm{Mg}$ filler metals after polarization tests are shown in Fig. 3(b), 4(b), 5(b), and 6(b), respectively. For comparison, the microstructures of these filler metals before corrosion polarization are also given in Fig. 3(a) to 6(a). In Fig. 3(a), the Al-12Si alloy reveals two distinct structures: a lamellar Al-Si eutectic structure and an $\alpha$-Al dendrite solid solution. Figure 3(b) shows that the Al-Si eutectic structure corrodes predominantly. Selective corrosion of the $\mathrm{Al}-\mathrm{Si}$ eutectic structure is attributed to the lower silicon content of the $\alpha$-Al dendrite solid solution. The scale of the Al-Si eutectic phase reduces at the addition of copper to the Ai-12Si alloy, as shown in Fig. 4(a). From Fig. 4(a), the microstructure of the Al-9.6Si-20Cu alloy consists of silicon particles surrounded with Al-Si eutectic, Al-Cu eutectic, and Al-Cu-Si ternary eutectic phases. In this case, localized corrosion cells are constructed between silicon particles and the surrounding eutectic phases, leading the corrosion current density of Al-9.6Si-
$20 \mathrm{Cu}$ to increase 12-fold more than that of the Al-12Si alloy. Figure 4(b) shows that the silicon particles act as cathodes while the $\mathrm{Al}-\mathrm{Cu}$ and $\mathrm{Al}-\mathrm{Si}-\mathrm{Cu}$ eutectic phases corrode preferentially. The microstructure of Al-7Si-20Cu-2Sn in Fig. 5(a) consists of an $\alpha-\mathrm{Al}$ solid solution, $\mathrm{CuAl}_{2}(\theta)$ intermetallic compounds, and $\mathrm{Al}-\mathrm{Cu}$ and $\mathrm{Al}-\mathrm{Si}-\mathrm{Cu}-\mathrm{Sn}$ eutectic phases. The disappearance of silicon particles (due to a decrease in the $\mathrm{Si}$ content of this alloy) is replaced by the formation of the $\mathrm{CuAl}_{2}$ $(\theta)$ phase. In this case, the corrosion current density ( $\left.I_{\text {corr }}\right)$ and the pitting tendency $(\Delta \Phi)$ of this filler metal are similar to those of the former Al-9.6Si-20Cu alloy. Figure 5(b) shows that the $\mathrm{Al}-\mathrm{Cu}$ and $\mathrm{Al}-\mathrm{Si}-\mathrm{Cu}-\mathrm{Sn}$ phases are in the selective corrosion regions. The addition of $1 \mathrm{wt} \%$ magnesium to the Al-7Si-20Cu-2Sn-1Mg alloy causes its corrosion potential to decrease to the most active value among all the Al-Si-Cu-based filler metals tested in this study, as indicated in Fig. 1. It also results in a drastic increase in corrosion current density and pitting tendency of this alloy, as shown in Table 1. From Fig. 6(a) as well as x-ray diffraction analyses conducted in a previous study, ${ }^{[6]}$ the $\mathrm{Al}-7 \mathrm{Si}-20 \mathrm{Cu}-2 \mathrm{Sn}-1 \mathrm{Mg}$ alloy contains an $\alpha-\mathrm{Al}$ solid solution, an $\mathrm{Al}-\mathrm{Si}-\mathrm{Cu}-\mathrm{Sn}$ eutectic phase, and various intermetallic compounds such as $\mathrm{CuAl}_{2}, \mathrm{CuMgAl}_{2}$, 

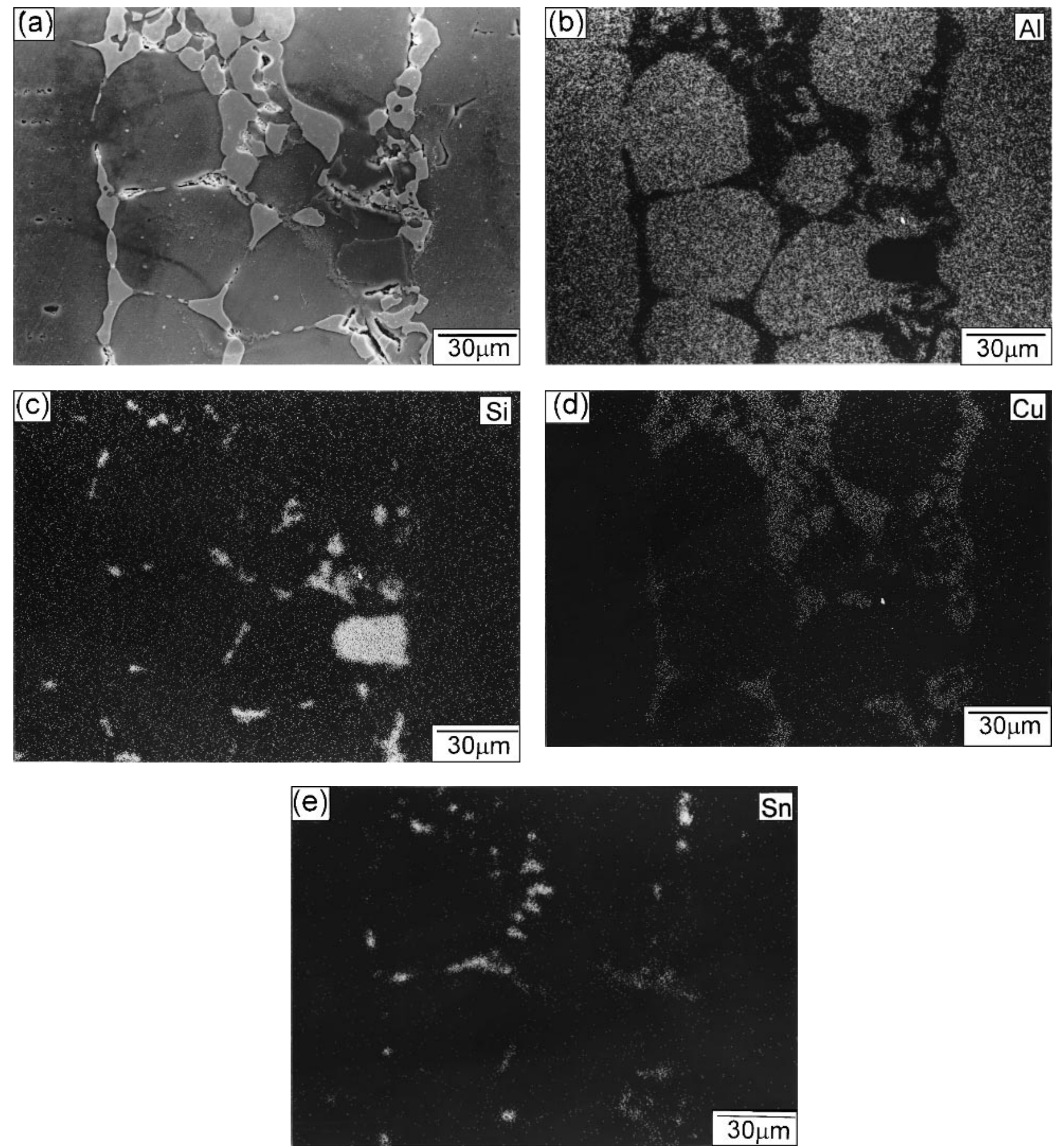

Fig. 8 EPMA element mapping of the 6061-T6 butt joint brazed with the Al-7Si-20Cu-2Sn filler metal at $550{ }^{\circ} \mathrm{C}$ for $30 \mathrm{~min}$

and $\mathrm{Mg}_{2} \mathrm{Si}$. After polarization testing, the preferential corrosion areas are located in the $\mathrm{Al}-\mathrm{Si}-\mathrm{Cu}-\mathrm{Sn}$ eutectic phase (Fig. 6b).

During brazing, the molten filler metal will react with the 6061-T6 base metal. It can be seen in Fig. 7 and 8 that meltingpoint depressants such as $\mathrm{Si}, \mathrm{Cu}$, and Sn penetrate intergranularly into the 6061-T6 base metal. The decrease in Si content of the brazement leads to the formation of coarse grains of the $\alpha-\mathrm{Al}$ solid solution. The remaining $\mathrm{Si}, \mathrm{Cu}$, and $\mathrm{Sn}$ elements are repulsed into the residual liquid region around the solidified coarse $\alpha$-Al grains. Eventually, the residual liquid region is also solidified into an intergranular phase in the brazement. It has been found in previous works ${ }^{[6,9]}$ that the 6061-T6 butt joints brazed with Al-Si-Cu-based filler metals are narrower 

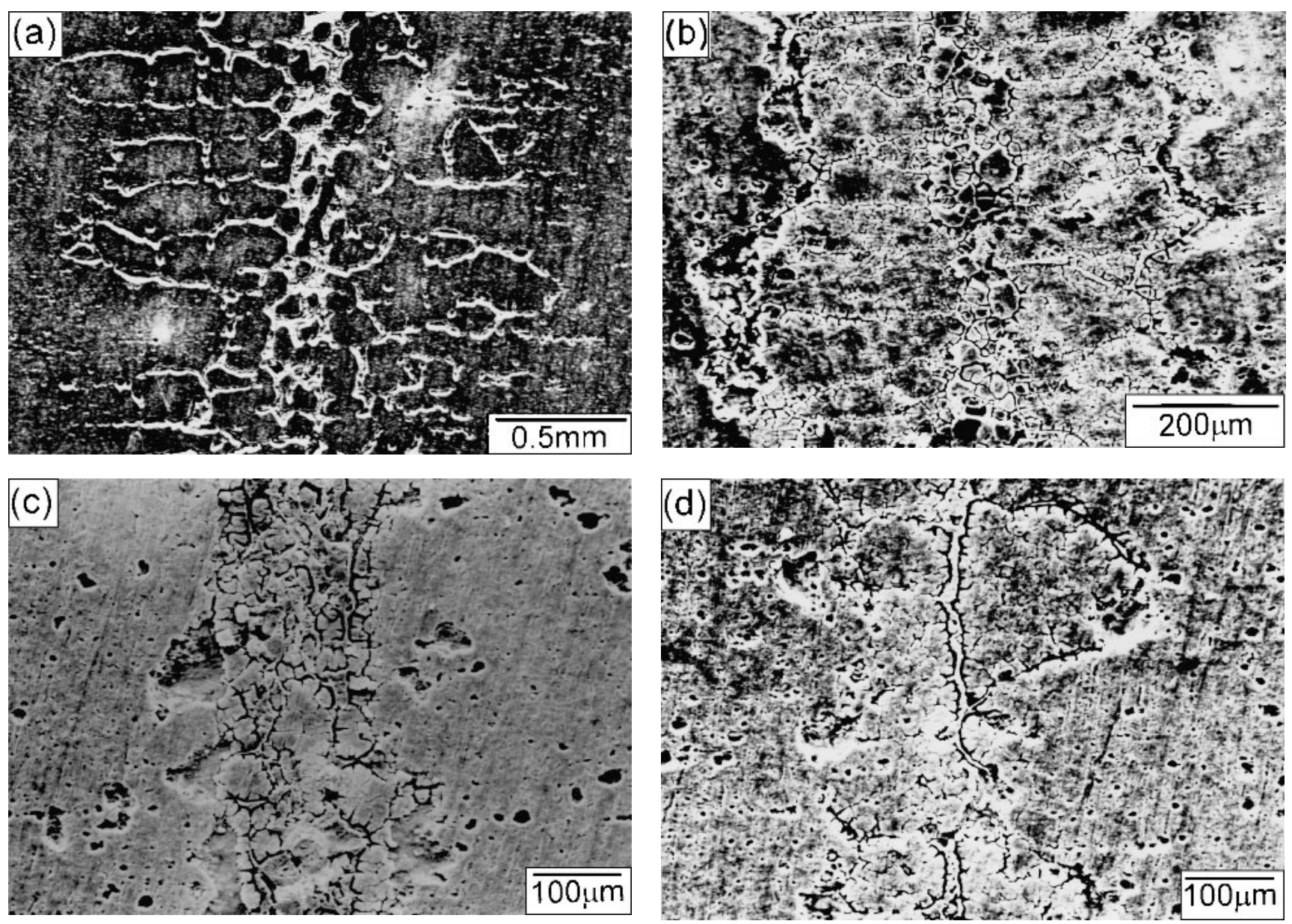

Fig. 9 Corroded surfaces of the 6061-T6 butt joints brazed with various filler metals after immersion tests in a $3.5 \% \mathrm{NaCl}$ aqueous solution for 7 days: (a) Al-12Si, (b) Al-9.6Si-20Cu, (c) Al-7Si-20Cu-2Sn, (d) Al-7Si-20Cu-2Sn-1Mg

than those brazed with Al-12Si filler metals due to the lower brazing temperatures in the former case. After immersion tests, the 6061-T6 brazements corrode preferentially in the butt-joint region, as shown in Fig. 9 and 10. The width of the corrosion region of the 6061-T6/Al-12Si brazement is about $1800 \mu \mathrm{m}$. It can be seen that selective dissolution of the Al-Si eutectic phase occurs at the 6061-T6/Al-12Si brazement, which is consistent with the observation of Kuroda and colleagues. ${ }^{[7,8]}$ The 6061-T6 butt-joint region is narrower, with a width lower than $750 \mu \mathrm{m}$. Figure 10 shows that severe corrosion occurs along the interface of the butt joint and the base metal, which is quite different from the case of the 6061-T6/Al-12Si brazement. The phenomenon can be explained by the larger difference of corrosion potentials between 6061-T6 alloy and Al-Si-Cu-based filler metals, which tends to incur severe galvanic corrosion. The bonding strengths of 6061-T6 butt joints brazed with various filler metals cited in this study are shown in Table 2 . The bonding strengths of various brazements after immersion tests in a $3.5 \% \mathrm{NaCl}$ aqueous solution for 7 days and 30 days are also listed in Table 2. It can be seen that the average degradation rates of the bonding strengths for various brazements after immersion tests vary quite little (ranging from $0.37 \mathrm{MPa}$ to $0.48 \mathrm{MPa}$ per immersion day). It is evident that, though $\mathrm{Al}-\mathrm{Si}$ $\mathrm{Cu}$-based filler metals display a lower corrosion resistance than
Al-12Si filler metal, the fact does not reflect on tensile testing of the corroded 6061-T6 butt joints brazed with these filler metals.

\section{Conclusions}

The corrosion potentials as measured for the alloys before brazing decline in the order Al-9.6Si-20Cu, Al-12Si, 6061-T6 $\mathrm{Al}, \mathrm{Al}-7 \mathrm{Si}-20 \mathrm{Cu}-2 \mathrm{Sn}$, and $\mathrm{Al}-7 \mathrm{Si}-20 \mathrm{Cu}-2 \mathrm{Sn}-1 \mathrm{Mg}$. The larger difference of corrosion potentials between 6061-T6 alloy and $\mathrm{Al}-\mathrm{Si}-\mathrm{Cu}$-based filler metals causes severe galvanic corrosion along their butt-joint fronts. However, in the case of 6061T6/Al-12Si brazement, corrosion occurs through selective dissolution of the Al-Si eutectic phase. Although the Al-Si-Cubased filler metals before brazing possess higher corrosion densities and pitting tendencies than the Al-12Si filler metal, the corrosion region of 6061-T6 butt joints brazed with Al12Si filler metal is much larger than those brazed with the $\mathrm{Al}-\mathrm{Si}-\mathrm{Cu}$-based filler metals. In the meantime, degradation rates of bonding strengths for various filler metals after immersion tests in a $3.5 \% \mathrm{NaCl}$ aqueous solution are similar to each another. 

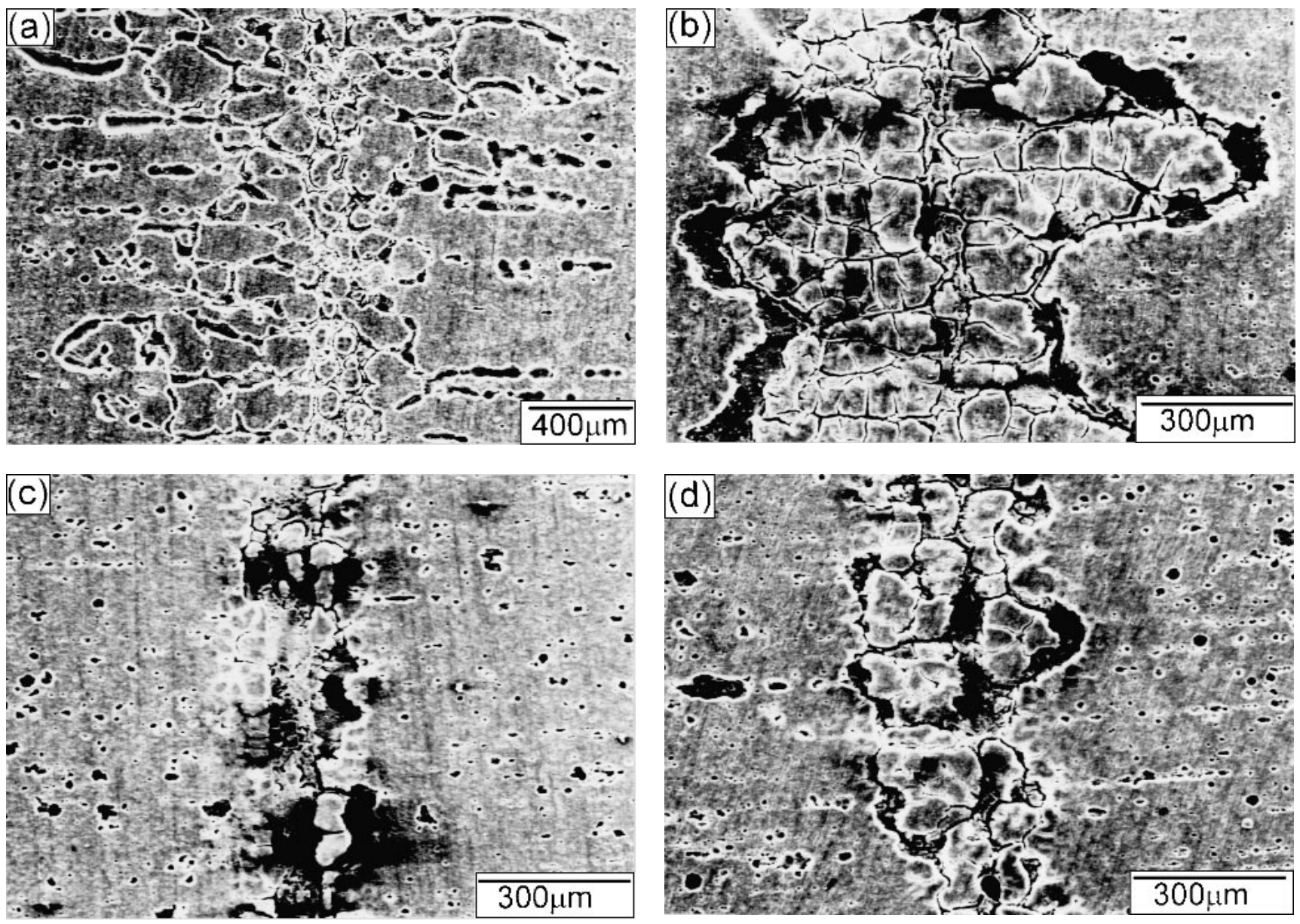

Fig. 10 Corroded surfaces of the 6061-T6 butt joints brazed with various filler metals after immersion tests in a $3.5 \% \mathrm{NaCl}$ aqueous solution for 30 days: (a) Al-12Si, (b) Al-9.6Si-20Cu, (c) Al-7Si-20Cu-2Sn, (d) Al-7Si-20Cu-2Sn-1Mg

Table 2 Bonding Strengths (MPa) of 6061-T6 Butt Joints Brazed with Various Filler Metals Before and After Immersion Tests in a 3.5\% NaCl Aqueous Solution for 7 Days and 30 Days

\begin{tabular}{|c|c|c|c|c|c|}
\hline Filler Metal & Brazing Conditions & $\begin{array}{c}\text { Initial } \\
\text { Joint Strength }\end{array}$ & $\begin{array}{c}\text { Joint Strength } \\
7 \text { Days }\end{array}$ & $\begin{array}{l}\text { Joint Strength } \\
\text { 30 Days }\end{array}$ & $\begin{array}{c}\text { Degradation } \\
\text { Rate }(\mathrm{MPa} / \mathrm{d})\end{array}$ \\
\hline $\mathrm{Al}-12 \mathrm{Si}$ & $600{ }^{\circ} \mathrm{C}, 30 \mathrm{~min}$ & 59 & 57 & 46 & 0.37 \\
\hline Al-9.6Si-20Cu & $550^{\circ} \mathrm{C}, 30 \mathrm{~min}$ & 41 & 36 & 30 & 0.48 \\
\hline $\mathrm{Al}-7 \mathrm{Si}-20 \mathrm{Cu}-2 \mathrm{Sn}$ & $550^{\circ} \mathrm{C}, 30 \mathrm{~min}$ & 62 & 59 & 49 & 0.43 \\
\hline Al-7Si-20Cu-2Sn-1Mg & $550^{\circ} \mathrm{C}, 30 \mathrm{~min}$ & 74 & 71 & 62 & 0.41 \\
\hline
\end{tabular}

\section{References}

1. Y. Sugiyama: "Brazing of Aluminum Alloys," Weld. Int., 1989, 3(8), pp. 700-10

2. H. Kawas, T. Takemoto, M. Asano, I. Kawakatsu, and K. Liu: "Study of a Method for Evaluating the Brazeability of Aluminum Sheet," Weld. J., 1989, 68(10), pp. 396s-403s

3. T. Hattori, S. Sakai, A. Sakamoto, and C. Fujiwara: "Brazeability of Aluminum in Vacuum-Nitrogen Partial-Pressure Atmosphere Brazing," Weld. J., 1994, 73(10), pp. 233s-40s.

4. G. Humpston, S.P.S. Sangha, and D.M. Jacobson: "New Filler Metals and Process for Fluxless Brazing of Aluminum Engineering Alloys," Mater. Sci. Technol., 1995, 11, pp. 1161-67.
5. D.M. Jacobson, G. Humpston, and S.P.S. Sangha: "A New LowMelting-Point Aluminum Braze," Weld. J., 1996, 75(8), pp. 243s-50s

6. M.S. Yeh, L.C. Tsao, T.C. Tsai, C.S. Wu, and T.H. Chuang: "Development of a Low Melting Point Filler Metal for Brazing Aluminum Alloys," Metall. Mater. Trans. A, 2000, 31A, pp. 2239-45.

7. S. Kuroda, T. Itagaki, and K. Tohma: "Electrochemical Property of Al-Si Alloy Filler," J. Jpn. Inst. Light Met., 1996, 46(3), pp. 113-18.

8. S. Kuroda, T. Itagaki, and K. Tohma: "Effect of Heat Treatment on Electrochemical Property of Al-Si Alloy Filler," J. Jpn. Inst. Light Met., 1996, 46(6), pp. 286-91.

9. L.C. Tsao, T.C. Tsai, C.S. Wu, and T.H. Chuang: "Brazeability of the 6061-T6 Aluminum Alloy with Al-Si-20Cu Based Filler Metals," $J$. Mater. Eng. Perform., 2001, 10, pp. 705-09. 